\title{
Phylogenetic relationships of gadfly petrels Pterodroma spp. from the Northeastern Atlantic Ocean: molecular evidence for specific status of Bugio and Cape Verde petrels and implications for conservation
}

\author{
JOSÉ JESUS, DÍliA MENEZES, SARA GOMES, PAULO OLIVEIRA, \\ MANUEL NOGALES and ANTÓNIO BREHM
}

\section{Summary}

It is widely accepted that the gadfly petrels of the Macaronesian islands comprise three closely related and morphologically similar taxa, Petrodroma madeira from Madeira island, $P$. deserta (also treated as P. feae deserta) from Bugio and P. feae (also treated as P. feae feae) from Cape Verde Islands. However, the taxonomic rank of each taxon is not well defined, and has been subject to a long debate. Partial sequences of cytochrome $b$ (893 bp) from 39 individuals (five from Madeira, 18 from nearby Bugio, and 16 from Fogo) and morphometric data from five characters from 102 individuals (74 from Bugio and 28 from Fogo in Cape Verde), were used to compare and estimate phylogenetic relationships and the taxonomic status of these petrels. In the phylogenetic analysis and sequence divergence estimation, we also include 23 sequences of 19 Pterodroma species available from GenBank. Our results show that Macaronesian gadfly petrels form a monophyletic clade. Birds from Bugio and Cape Verde are the most closely related taxa followed by those from Madeira. The group formed by the three taxa studied is closely related to Bermuda Petrel P. cahow and Black-capped Petrel P. hasitata. A hypothesis for the colonization of the islands is presented. The level of sequence divergence is sufficient to consider the populations of Bugio and Cape Verde as separate species. Reproductive isolation is supported by exclusive haplotypes and fixed changes. Despite the presence of some significant differences in bill and tarsus measurements, the two species seem to be morphologically similar because the great overlap of variation intervals in the measurements hinders identification. It therefore appears suitable for consideration as a cryptic species. An important conservation implication is that the world population of both species is very small; if treated as a full species, deserta on Bugio may qualify for uplisting to 'Vulnerable' on the IUCN Red List.

\section{Introduction}

Petrels of the genus Pterodroma form the largest group of tube-nosed birds, consisting of 29 species with a geographical distribution range covering the Atlantic, Indian and Pacific Oceans (Imber 1985). Gadfly petrels of the genus Pterodroma are represented in the Northeast Atlantic by three breeding colonies, located on Madeira Island itself, Bugio (one of the nearby Desertas islets) and the Cape Verde Islands. The taxonomy of these petrels has been controversial and subject to discussion (see for example Mathews 1934a, b, Imber 1985, Zino and Zino 1986, Zino et al. 2008), mainly due to their morphological similarities. 
In the past, colonies were considered as different subspecies within Soft-plumaged Petrel P. mollis, a species with a wide geographical distribution throughout the Antarctic or Southern Ocean, Indian and Atlantic Oceans, characterized by variations in morphology, colouration and breeding behaviour (Bretagnolle 1995). The individuals breeding on Bugio were considered as P. $m$. deserta, and those from Cape Verde islands as P. m. feae (Mathews 1934a, b, Bannerman and Bannerman 1965, 1968). Bourne (1955) suggested raising the taxon from Bugio to specific level, P. deserta.

Based on morphology, colouration and calls, Bretagnolle (1995) suggested splitting P. mollis into two distinct species: P. mollis in the South Atlantic and P. feae in the North Atlantic, with subspecies P. f. feae, P. f. madeira and P. f. deserta assigned to Cape Verde, Madeira and Bugio respectively. Other studies (Bourne 1983, Imber 1985, Warham 1990) proposed splitting the Northeastern Atlantic petrels from the P. mollis complex and suggested a species rank for the birds of Madeira (P. madeira) and those of Bugio and Cape Verde islands (P. feae).

Recently, using morphological and mitochondrial DNA sequence data (cytochrome $b$ ), Zino et al. (2008) concluded that breeding colonies from Madeira and Desertas should be considered different species, as already suggested by previous studies (Bourne 1983, Imber 1985, Zino and Zino 1986). Emphasizing the recognition of the Madeira and Desertas gadfly petrels as distinct species, Sangster et al. (2002) suggested that they diverged 840,000 years ago, in the Early Pleistocene.

Petrels from Bugio have been found to be morphologically similar to those from Cape Verde (Mathews 1934a, Bourne 1957, Jouanin et al. 1969, Cramp and Simmons 1977, Jouanin and Mougin 1979) in spite of some differences in morphometrics (Bretagnolle 1995) and breeding phenology (Bannerman and Bannerman 1968). Usually, Cape Verde petrels lay in December and January within a breeding period between November and May, which is clearly distinct from other Macaronesian petrels.

Based on behavioural differences related to breeding, Ratcliffe et al. (2000) suggested that Bugio and Cape Verde petrels are probably cryptic species. It was also found that Cape Verde petrels appear to have darker upper tail coverts, moderate to heavy barring on the side feathers near the base of the wings, and heavily marked and mottled and flanks, which is rarely seen in Bugio petrels (Bretagnolle 1995, Hazevoet 1995, Patteson and Brinkley 2004). However, in some cases, the differentiation of Cape Verde petrel from mollis is more difficult than from the Bugio petrel (Patteson and Brinkley 2004).

The main aim of this study was to elucidate the taxonomic position of the gadfly petrels of genus Pterodroma from Bugio and Cape Verde islands within the clade of North Atlantic Pterodroma petrels, and the relationships between the forms from Bugio and Cape Verde islands, using sequence and morphological data. We followed the suggestions of Proudlove and Wood (2003) recommending the combination of both traditional characters (such as phenotypic or behavioural traits) and DNA techniques in taxonomic arrangements. For this purpose, we used the mitochondrial cytochrome $b$ gene (thereafter cyt-b) which has been widely used in vertebrate systematics and phylogenetics to resolve divergences at various taxonomic levels (e.g. Nunn and Stanley 1998, Farias et al. 2001, Zino et al. 2008).

\section{Study area}

The Macaronesian islands consist of the archipelagos of the Azores, Madeira, the Selvagens, the Canaries and Cape Verde (Báez and Sanchez-Pinto 1983). All these islands are of volcanic origin and are situated between $14^{\circ} 49^{\prime}$ and $39^{\circ} 45^{\prime} \mathrm{N}$, and $13^{\circ} 20^{\prime}$ and $31^{\circ} 17^{\prime} \mathrm{W}$ (Báez and SánchezPinto 1983; Figure 1).

Madeira is located about $700 \mathrm{~km}$ from the West African coast and about $900 \mathrm{~km}$ from the Iberian Peninsula. Madeira Island is the largest of its archipelago with $728 \mathrm{~km}^{2}$. Bugio, one of the three Desertas islands, is located about $30 \mathrm{~km}$ from Madeira and is a small islet, with an area of about $3 \mathrm{~km}^{2}$. Madeira and Bugio belong to the same geological complex and seem to have 


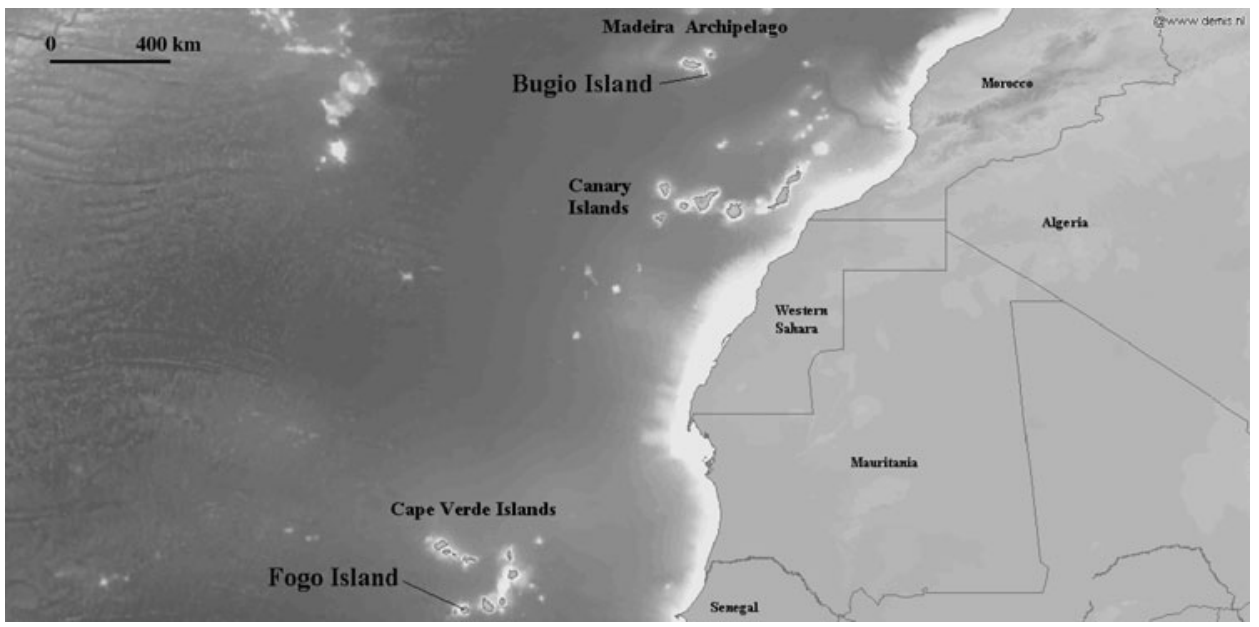

Figure 1. Map showing Bugio and Fogo sampling localities of gadfly petrels Pterodroma spp. in the Macaronesian islands.

slightly different ages of emergence, around 4.6 million years for Madeira and 3.6 for Desertas islands (Geldmacher et al. 2000).

The Cape Verde archipelago is located about $500 \mathrm{~km}$ from the West African coast, and about $1,300 \mathrm{~km}$ south of the Canary Islands. Fogo is the fourth biggest island of the archipelago with about $476 \mathrm{~km}^{2}$ (Costa 1998). According to Mitchell-Thomé (1985), the island of Santiago, the neighbour island of Fogo, emerged about 10.3 million years ago.

\section{Materials and methods}

\section{Sampling and molecular methods}

The number and geographic locations of the birds included in this study are given in Appendix 1 (in Supplementary materials) and Figure 1 . Fifty to one hundred $\mu$ l of blood were obtained from the brachial vein and preserved in $100 \%$ ethanol. In the laboratory, the blood was dried on a piece of sterilized filter paper. DNA was then extracted using the extraction kit 'Isolation of Genomic DNA from Dried Blood Spots' (QIAamp DNA Micro Kit, Cat. No. 56304) following the manufacturer's instructions. PCR primers used in amplification of the cyt- $b$ gene were Li4987: 5'TATTTCTGCTTGATGAAACT3'; and H16025: 5'CTAGGGCTCCAATGATGGGGA3' (both modified from Gómez-Díaz et al. 2006). An internal primer was designed by us and used for sequencing (Pterodroma_intıFor, 5'GAGGACAAATATCATTCTGAG3'). The PCR cycling procedure was as follows: An initial denaturation step: $30 \mathrm{os}$ at $94^{\circ} \mathrm{C} ; 40$ cycles: denaturation for $30 \mathrm{~s}$ at $94^{\circ} \mathrm{C}$, primer annealing for $30 \mathrm{~s}$ at $50^{\circ} \mathrm{C}$; extension for $30 \mathrm{~s}$ at $72^{\circ} \mathrm{C}$; and a final step of $5 \mathrm{~min}$ at $72^{\circ} \mathrm{C}$. PCR fragments were sequenced in an ABI 310 sequencer (Applied Biosystem DNA Sequencing Apparatus). The primers used for sequencing were the same as those used in the amplification.

DNA sequences were aligned using ClustalW (Thompson et al. 1994) as implemented in MEGA version 4 (Tamura et al. 2007) sequence alignment editor and subjected to visual inspection whenever necessary. No ambiguous alignments and no indels were found. Sequences were compared with closely related species to check for possible errors. The alignment is available on request from the corresponding author. 
Phylogenetic relationships among taxa were estimated from these sequences. To assess genetic distances and haplotypes between the three forms of gadfly petrel from the Macaronesian region, we also included three more samples from Madeira itself and two from the Desertas in the analysis, both retrieved from GenBank (marked with * in Appendix 1 in Supplementary materials). These five samples were not included in the phylogenetic analysis because they had a significant portion of missing data (not overlapping with our sequences).

In total, 39 Pterodroma partial cyt- $b$ sequences from the Macaronesian region were obtained (five from Madeira Island, 18 from Bugio and 16 from Fogo) (see Appendix 1 in Supplementary materials). For phylogenetic analysis, we compared these to 18 partial sequences of cyt- $b$ belonging to other Pterodroma species retrieved from GenBank, which were fully overlapping with our 893 bp sequences. We also included in this analysis partial sequences of cyt- $b$ from two outgroups: one individual of Bulwer's Petrel Bulweria bulwerii (GenBank accession number, AJoo4156) and one of Cory's Shearwater Calonectris diomedea (GenBank accession number, AJoo4160) (Appendix 1 in Supplementary materials).

\section{Phylogenetic analysis}

True evolutionary relationships may be obscured in DNA sequence data sets if sites have become saturated by multiple substitutions (Swofford et al. 1996). To test for saturation, observed pairwise proportions of transitions and transversions were plotted against sequence divergence and calculated using DAMBE version 4.2.13 (Xia and Xie 2001).

The data were imported to PAUP* ${ }^{*}$.ob1o (Swofford 2002) and MEGA version 3.I (Kumar et al. 2004). For the phylogenetic analyses, we used maximum likelihood (ML) and Bayesian analyses. We followed the approach outlined by Huelsenbeck and Crandall (1997) to test 56 alternative models of evolution, employing PAUP* 4 .obio and Modeltest 3.7 (Posada and Crandall 1998). Once an evolution model was chosen according to Akaike Information Criterion, following Posada and Buckley (2004), it was used to estimate a tree using ML criteria (Felsenstein 1985). A heuristic search with tree bisection reconnection (TBR) and 1o replicates of random addition of taxa was performed to estimate a tree. The relative robustness of each dichotomy was established by bootstrap analysis. Non-parametric bootstrap support for nodes was estimated using the 'fast' option with 100 heuristic bootstrap replicates implemented in PAUP* 4.obıo. The Bayesian analysis was implemented using MrBayes v3.1.2. (Huelsenbeck and Ronquist 2001), which calculates Bayesian posterior probabilities using a Metropoliscoupled, Markov chain Monte Carlo (MC-MCMC) analysis. Bayesian analyses were conducted with random starting trees, four MCMC chains (one cold, three heated), run to $0.5 \times 10^{7}$ generations, and sampled every 100 generations using a General-Time-Reversible model of evolution with a gamma model of among-site rate variation. Additional Bayesian analyses were conducted with random starting trees, four MCMC chains (one cold, three heated), run $1 \times 10^{7}$ generations. Similar results were obtained as when only $0.5 \times 10^{7}$ generations were considered. In all searches, stationarity of the Markov Chain was determined as the point when sampled negative log likelihood values plotted against the number of generations reached a stable mean equilibrium value; 'burn-in' data sampled from generations preceding this point were discarded. The burn-in value was 2,500. Two independent replicates were conducted and inspected for consistency to check for local optima. Convergence between runs (as measured by effective sample size, ESS) and posterior probabilities of the estimates were determined using the software program Tracer (Rambaut and Drummond 2005). According to Ho et al. (2005), the effective population size is influenced not only by the number of samples drawn from the MCMC but also by the degree of autocorrelation among samples. The preliminary analysis revealed that the burn-in was sufficient. This was confirmed by a posterior analysis of the MCMC samples with the program Tracer. All data collected at stationarity were used to estimate posterior nodal probabilities and a summary of phylogeny. These posterior probabilities of each clade were used as support measure. 


\section{Morphometric analysis}

In total, 102 petrels were examined, 28 from Fogo and 74 from Bugio. Only adult birds were considered for measurements to prevent allometric bias for the comparison of populations. Due to lack of sexual dimorphism in Pterodroma spp., all individuals were considered on a single data matrix. Measurements of captured live individuals were recorded and five morphometric characters were taken for each individual.

Bill measurements (height and two length parameters; Figure 2) were recorded to the nearest $0.05 \mathrm{~mm}$ using callipers. Wing length and tarsus length were recorded to the nearest $\mathrm{mm}$ using a wing rule and a calliper, respectively. The weight was recorded, but was not considered in this study because birds were captured at different times of the year.

For sample comparisons, we used the Student t-test when parametric conditions were satisfied or Mann-Whitney when data did not accomplish parametric conditions. The statistical analyses were performed using the SPSS 12.0 package.

\section{Results}

Sequence and phylogenetic data

Plots of observed pairwise divergences of haplotypes for transitions and transversions in the separate codon positions and in all codon positions against total sequence divergence revealed that only the third position showed some saturation in transitions (Figure 3). This was not sufficient

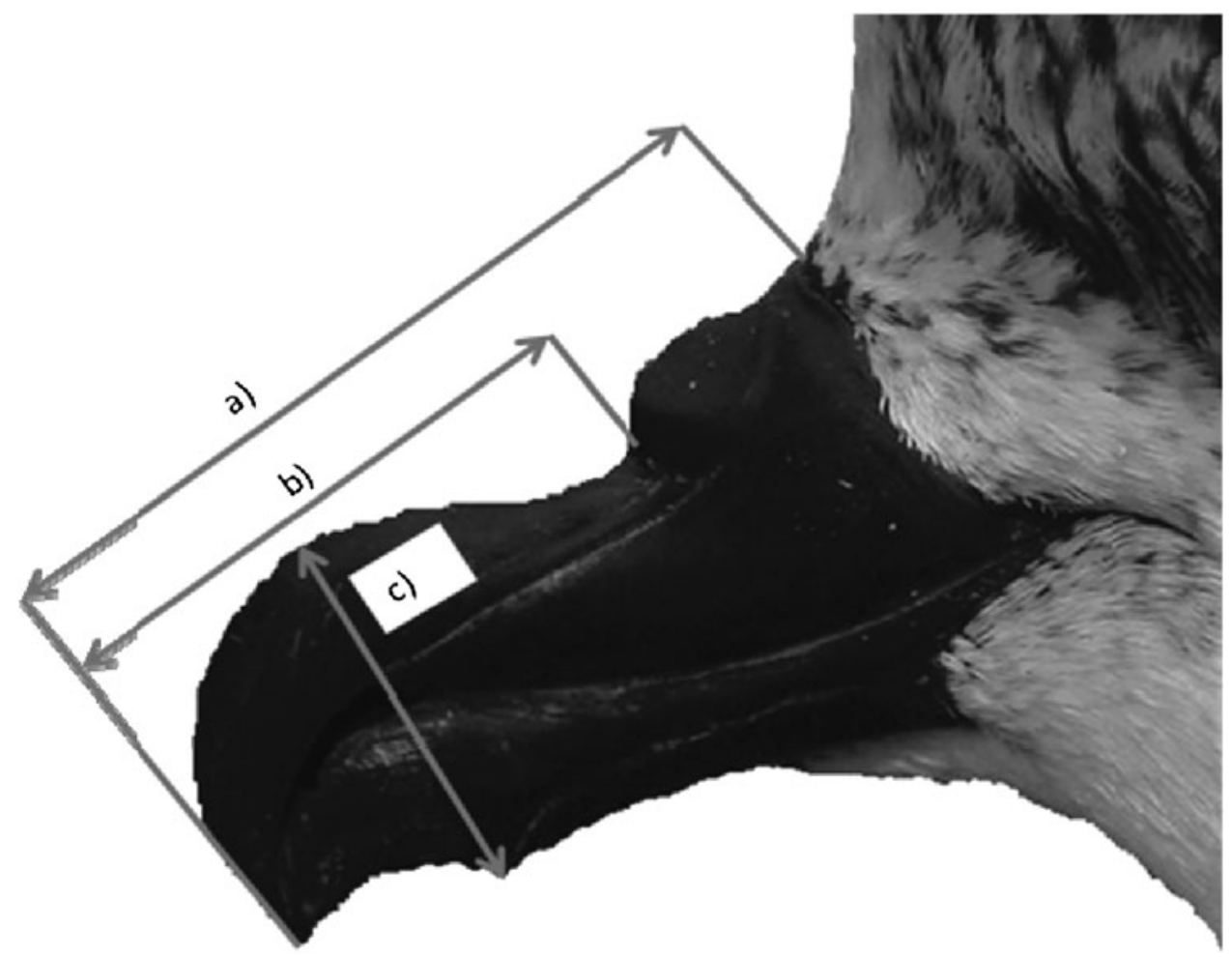

Figure 2. Measurements used to characterize the bill of gadfly Petrels Pterodroma spp. from Bugio and Fogo. 
(a)

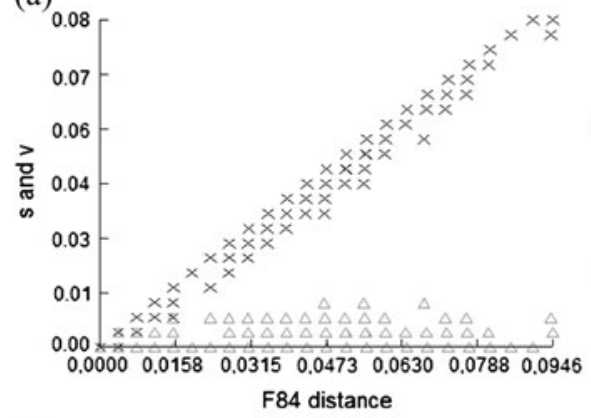

(c)

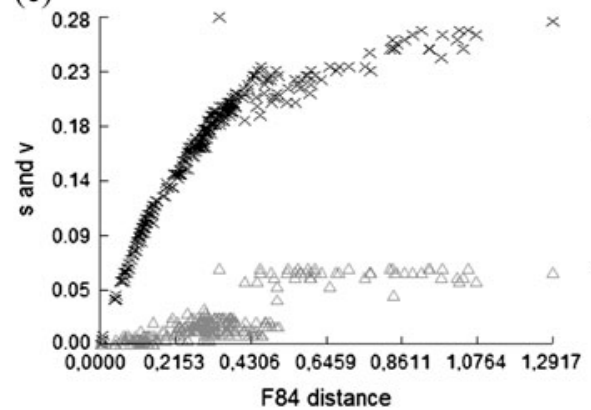

(b)

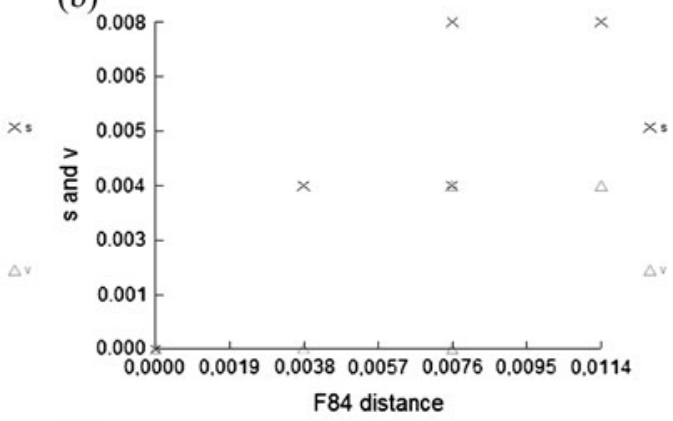

(d)

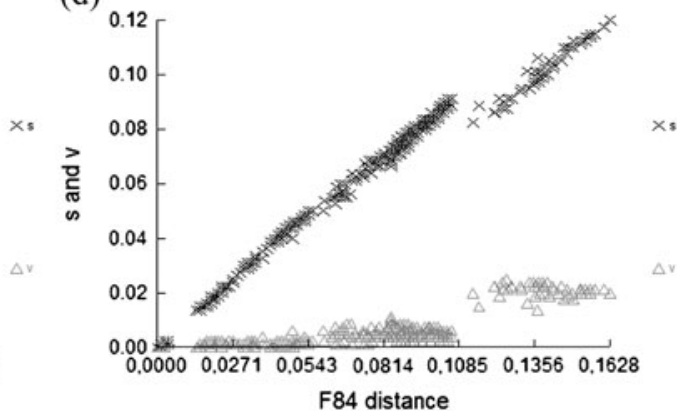

Figure 3. Observed number of transitions and transversions against F84 distances (Felsenstein 1993) for (a) codon position 1 , (b) codon position 2, (c) codon position 3 and (d) all codon positions. $\mathrm{X}-$ transitions, $\Delta-$ transversions.

to be excluded from the analysis since this is only necessary when ts/tv is approximately $I$ (Mindell and Honeycutt 1990), which is not the case here.

Amplified cytochrome $b$ fragments yielded unambiguous sequences of $893 \mathrm{bp}$ in length, with 255 variable sites of which 173 were parsimony informative and 82 were singletons. No insertions or deletions were observed. Low guanine content, lack of alignment problems and the similarity with cyt- $b$ sequences of the same genus or species, suggests that nucleotide sequences represent mitochondrial genes rather than nuclear pseudogenes (Zhang and Hewitt 1996). The best model for the data was the GTR model (Rodríguez et al. 1990) $(-\ln L=3842.8$ ), with a discrete approximation to a gamma-distributed rate-heterogeneity model $(\alpha=6.618)$, and an estimate of invariable sites $(\mathrm{I}=0.683$ ). A heuristic search incorporating this model found a single tree of $-\operatorname{lnL} 3837.8$. The topology of the best tree derived from ML analysis is very similar to that obtained from Bayesian analysis. The differences found in tree topology between the bootstrap 50\% majority-rule consensus ML tree and the tree derived from Bayesian analysis (using a GTR $+\mathrm{I}+\mathrm{G}$ model), are essentially related to significant differences in the support values, being much higher on the Bayesian tree, and thus creating more politomies on the ML tree. This results in branch order changes and a lower resolution of the tree to separate the various clades. However, the arrangement of the Macaronesian forms and the closest species to this group is very similar in both analyses.

The node that separates Bugio from Fogo (Cape Verde) individuals is better supported in the Bayesian topology (posterior probabilities $=1.0$ ) than in the ML tree (bootstrap value $=53$ ). The group formed by individuals from Bugio and Fogo is separated from those from Madeira by a relatively high posterior probability value (0.7). 
Table 1. Descriptive statistics of cytochrome $b \mathrm{~K}_{2} \mathrm{P}$ pairwise distances between the three forms of $\mathrm{NE}$ Atlantic gadfly petrels. In each cell, the upper line gives mean \pm standard deviation; the lower line gives the maximum and minimum. Gaps/Missing Data were treated with the option Pairwise Deletion as implemented in MEGA version 4.0 (Kumar et al. 2004).

\begin{tabular}{|c|c|c|c|}
\hline & Madeira & Bugio & Fogo (Cape Verde) \\
\hline Madeira & $0.0016 \pm 0.001[0.003 ; 0]$ & $0.024 \pm 0.002[0.02 ; 0.03]$ & $0.023 \pm 0.002[0.02 ; 0.03]$ \\
\hline Bugio & & $0.0005 \pm 0.001[0.0033 ; 0]$ & $0.016 \pm 0.001[0.015 ; 0.02]$ \\
\hline Fogo (Cape Verde) & & & $0.0015 \pm 0.001[0.005 ; 0]$ \\
\hline
\end{tabular}

Based on Kimura's 2-parameter distance (Kimura 1980), the average sequence divergence between populations from Bugio and Fogo is approximately $1.58 \%$ (minimum $=1.5$; maximum $=$ $2.0 \%$ ) (Table 1 ). Though the average value of sequence divergence is low, it is higher than that between P. macroptera and P. lessonni (1.2\%), and near to the value obtained between P. magentae and P. lessonii ( $1.7 \%$ ) (Appendix 2 in Supplementary materials). The average sequence divergence between Madeira and Bugio, and Madeira and Fogo, is around 2.3 and 2.4 respectively, which is similar to, or slightly higher than, the value found between the pairs P. macroptera / P. incerta (2.2\%), P. magentae / P. macroptera (2.1\%), P. lessonii / P. incerta (2.1\%), and higher than value for P. magentae / P. lessonii (1.7\%) and P. magentae / P. incerta (1.9\%) (Appendix 2 in Supplementary materials).

Intra-island cyt- $b$ divergences are substantially lower than inter-island divergences. Average sequence divergence varies from $0.05 \%$ for Bugio to $0.16 \%$ for Madeira, with Fogo showing $0.15 \%$ (Appendix 2 in Supplementary materials). An important result is that no haplotypes are shared between the three populations (Table 2). Overall, Madeira, Bugio and Fogo constitute a single clade, suggesting a common ancestor (Figures 4,5 and 6).

\section{Morphometric data}

From the five morphometric characters studied, four of them showed statistical differences. Birds from Bugio showed bills significantly longer than those from Fogo $(t=7.14, P<0.005$; for bill length) $(t=7.76, P<0.005$; for bill nose length $)$ and higher $(t=11.86, P<0.005)$. The tarsus was also significantly longer in the Bugio population than in Fogo $(t=6.22, P<0.005$; Table 3).

\section{Discussion}

\section{Patterns of colonization}

The analysis of cyt- $b$ sequences produced robust estimates of relationships for the populations of the three islands, particularly for Bugio and Fogo. The results suggest monophyly of the group of Macaronesian gadfly petrels, indicating a single initial colonization event on one island, probably Cape Verde, followed by radiation to the other islands. Despite the low level of support obtained from the ML analysis, the close relationships of the Macaronesian gadfly petrels to P. cahow and P. hasitata are evident in both analyses, as obtained by Zino et al. (2008).

Considering a molecular clock in other medium-sized procellariforms of about $0.78 \%$ divergence per Myr (or $0.9 \%$ using the Kimura two-parameter correction) for cyt- $b$ (Nunn and Stanley 1998), Bugio and Fogo diverged approximately 1.75 million years ago (between the Pliocene and Pleistocene).

According to Bourne (1983) and Zino et al. (2008) the archipelago of Madeira may have been colonised twice by gadfly petrels, one event being responsible for the origin of P. madeira and the other for the origin of $P$. deserta. P. madeira may have evolved on Madeira when the climate was cooler and wetter during the Pleistocene. Then, as the climate became warmer and drier, P. madeira 
Table 2. Variable sites of the cytochrome $b$ gene sequences in 35 individuals of Macaronesian gadfly petrels (individuals with sequences containing missing data were disregarded).

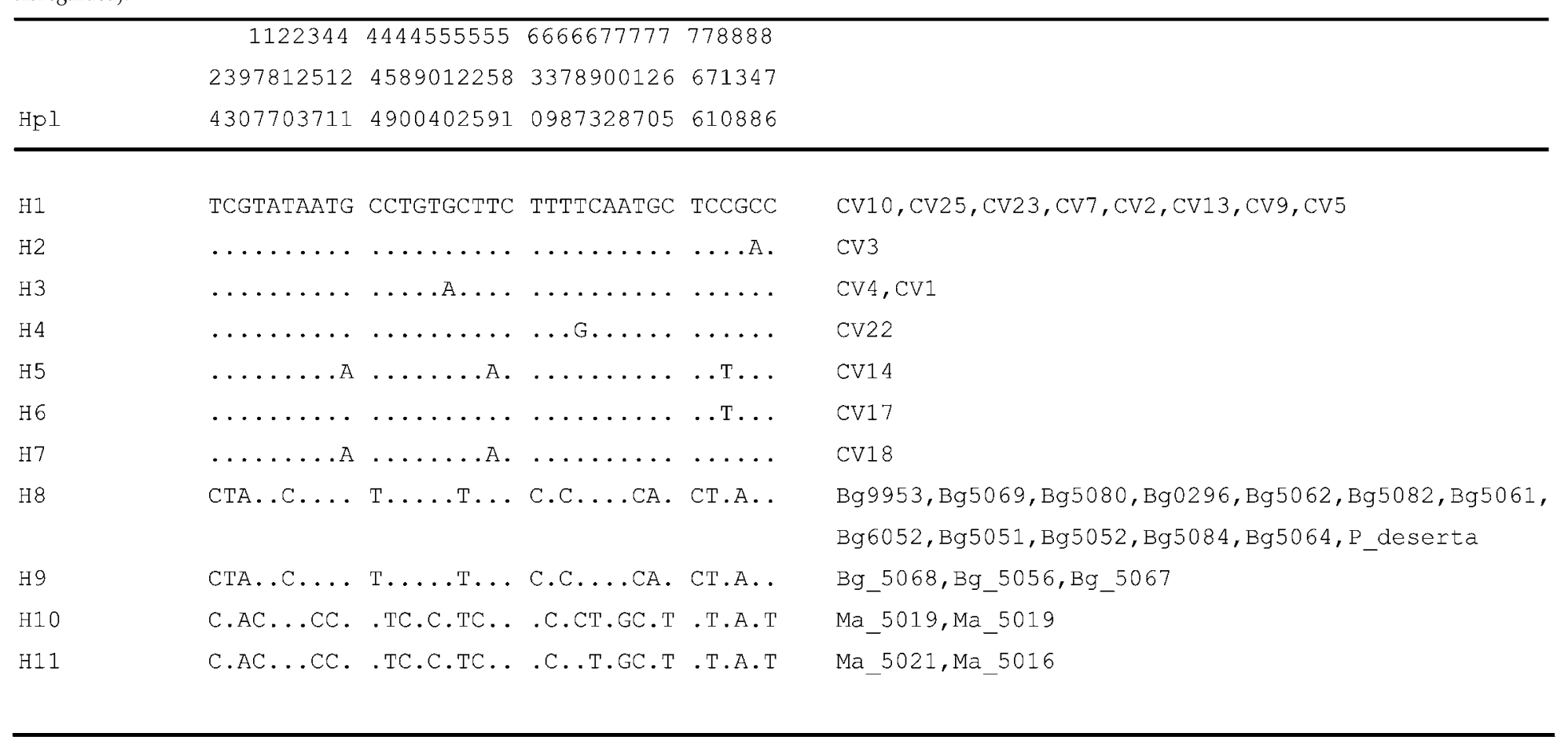


Table 3. Morphometric measurements of Bugio and Fogo gadfly petrels Pterodroma spp.

\begin{tabular}{lll}
\hline & Bugio & Fogo \\
\hline Wing length & & \\
Mean \pm SD & $270.7 \pm 10.6$ & $270.2 \pm 5.0$ \\
Range & $226-283$ & $263-279$ \\
$n$ & 74 & 28 \\
Tarsus length & & \\
Mean \pm SD & $35.8 \pm 1.2$ & $34.2 \pm 1.1$ \\
Range & $32.7-38.9$ & $31.2-36.5$ \\
$n$ & 74 & 28 \\
Bill length & $29.6 \pm 1.0$ & $27.9 \pm 1.0$ \\
Mean \pm SD & $27.9-32.0$ & $26.0-29.8$ \\
Range & 65 & 28 \\
$n$ & & \\
Bill height & $12.6 \pm 0.66$ & $11.3 \pm 0.39$ \\
Mean \pm SD & $11.0-14.4$ & $10.6-12.1$ \\
Range & 65 & 28 \\
$n$ & & \\
Bill nose length & $21.6 \pm 0.84$ & $20.2 \pm 0.69$ \\
Mean \pm SD & $19.4-23.6$ & $19.3-21.5$ \\
Range & 65 & 28 \\
$n$ & & \\
\hline
\end{tabular}

retreated to higher altitudes of Madeira where the climate was cooler and wetter, whilst Bugio was colonised by petrels migrating from the arid environment of Cape Verde, a picture that is somewhat supported by our data.

In fact, our results suggest that petrels from Cape Verde may have colonized Madeira during the Pliocene, followed by their speciation on this island, as suggested by Bourne (1983) and Zino et al. (2008). In the Pliocene, Madeira was probably hotter and drier than in the Pleistocene since some data seem to indicate the presence of savanna vegetation at the same latitude in Africa (Hernández-Fernández and Vrba 2006). The change from Pliocene to Pleistocene occurred around 1.6-1.8 million years ago (Teixeira et al. 1979), followed by the beginning of the Ice Age, characterized by a significant reduction in temperature. It was probably during this change that petrels from Cape Verde colonized Bugio, possibly due to the greater similarity of its environment to Cape Verde than to that prevailing in Madeira.

\section{Taxonomic status of Bugio and Fogo gadfly petrels}

Here we present the first molecular data comparing Bugio and Fogo gadfly petrels. These two forms should be considered as two distinct species, following the suggestion of Ratcliffe et al. (2000). The names may correspond to their elevation from subspecies to species. On Bugio, P. deserta should be considered while on Fogo it should be P. feae (the name given by Salvadori in 1899 to Cape Verde petrels). There is no evidence of any close relationship with P. mollis (see for example, Mathews 1934a, b, Bannerman and Bannerman 1965, 1968, Imber 1985). The following paragraphs will explain why we suggest and advocate species status for these two forms.

The genetic diversity within each island is significantly low when compared to genetic diversity among islands. The values for divergence between the two forms are higher than between Greatwinged Petrel P. macroptera and White-headed Petrel P. lessonii, considered as two legitimate species. These values are not abnormal for species divergence as lower levels (near or even less than $1 \%$ ) are found in other closely related birds (Johnson 2001), particularly other Pterodroma species ( $1 \%$ between Henderson Petrel P. atrata and Herald Petrel P. heraldica) (Brooke and Rowe 1996). Also, when compared with other vertebrates, birds have lower levels of genetic 


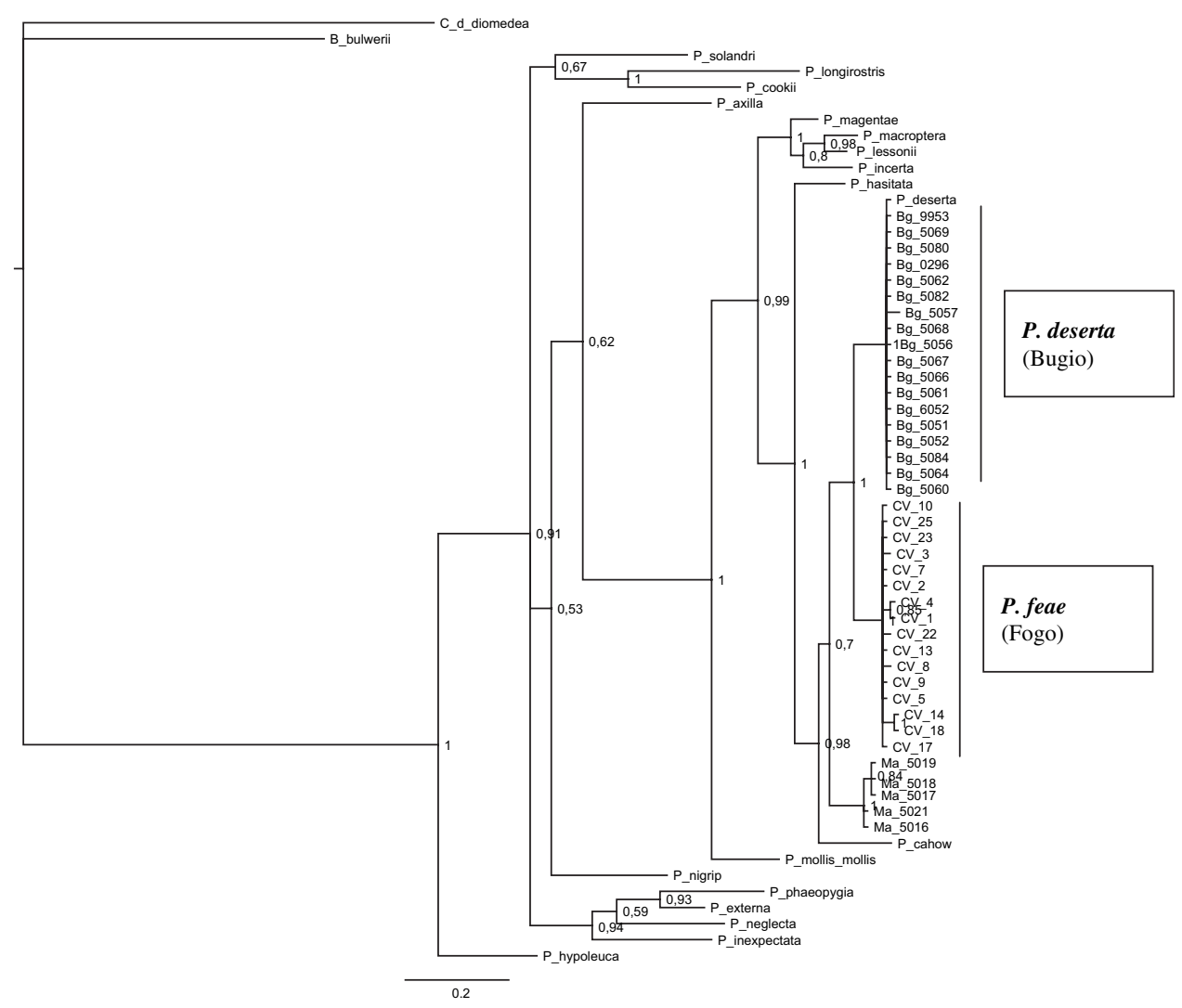

Figure 4. Tree derived from Bayesian analysis of cytochrome $b$ fragment, using a GTR+G+I approximation. Average posterior probabilities are shown near nodes. The posterior probability indicates the probability that the clade is correct under the model. Polytomous nodes indicate that the resolutions of the nodes involved have posterior probabilities less than 0.5 . The tree was rooted using Bulweria bulwerii and Calonectris diomedea.

divergence between groups of similar taxonomic ranks for a variety of nuclear and mitochondrial markers, a phenomenon known as the Avian Constraint Hypothesis (Stanley and Harrison 1999).

One of the requisites of the biological species concept is the reproductive isolation of the species (Mayr 1942). Our data suggest reproductive isolation between Bugio and Fogo islands, since no haplotypes are shared between the two populations. Also, all the birds from Bugio examined in this study were ringed and not captured in the Cape Verde archipelago, despite the limited capture effort made in the latter. About 10\% of Bugio birds were recaptured in Bugio (unpublished data). Birds appear to breed on the island on which they were born (philopatry). However, this information is only true for females, because mtDNA reflects female-mediated gene flow only. One hypothetical problem would be the mixture of the two populations during the non-breeding period, and the copulation between males from one population with females from another. However it is almost impossible or at least improbable, because both species are allochronic breeders with two distinct reproductive periods: Cape Verde petrels lay in December and January (breeding period from November to May) (Bannerman and Bannerman 1968, Cramp and Simmons 1977), and Bugio Petrels lay in July and August (breeding period June to December) (Bourne 1957). In fact, the breeding season allochrony has been shown to be an important 


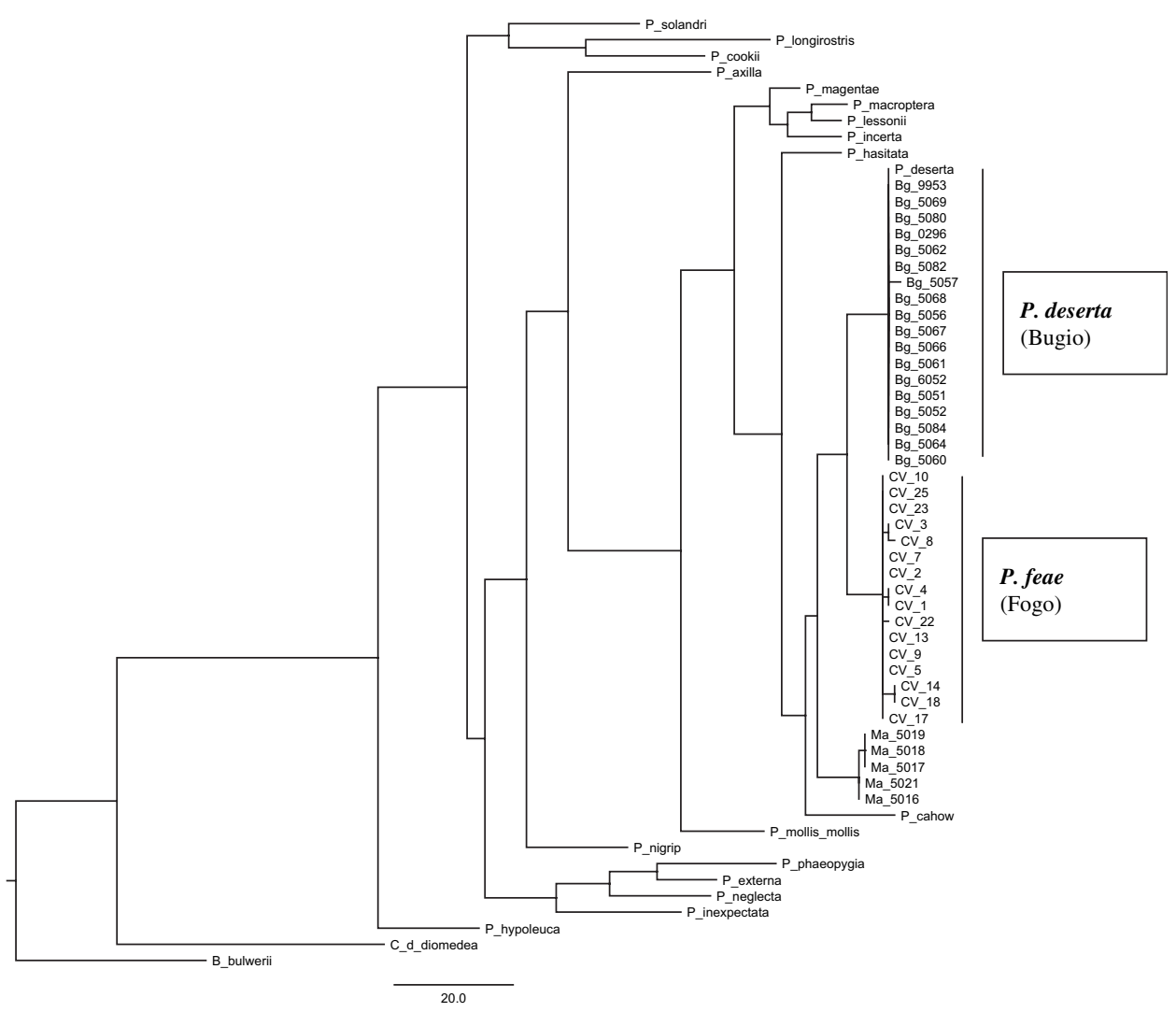

Figure 5. Single best tree derived from a ML analysis using the model and the tree search method described in the text. The tree was rooted using Bulweria bulwerii and Calonectris diomedea.

isolating mechanism in seabirds, as seen in the populations of Band-rumped Storm-petrels Oceanodroma castro (Friesen et al. 2007b, Smith and Friesen 2007). These authors found genetic differences in sympatric seasonal populations, which were considered a case of sympatric speciation. In our study, the two groups are allochronic and the isolation is enhanced by the fact they are allopatric, which even in neighbouring islands can also be an important isolating mechanism, as found with Dark-rumped Petrel P. phaeopygia in the Galápagos (Friesen et al. 2006). Our two groups are geographically very distant. The study of Friesen et al. (2006) led us to formulate the following questions that must be solved in future: 1) Are the colonies of Cape Verde Fea's Petrel isolated and differentiated? and 2) Are the petrels found in the Azores (presumably P. feae - see Monteiro and Furness 1995) isolated? Interestingly, those authors (Monteiro and Furness, 1998) found not only the same type of speciation due to allochronous breeding season in $O$. castro, but also found that allopatric breeders with the same season were morphologically similar, and sympatric breeders with a different season were morphologically significantly different, a good example of character displacement. In our case, we have allopatric breeders with a different season. Bearing in mind the conclusions of the latter study, allopatry could well be the reason why the forms from Bugio and Cape Verde are morphologically similar.

No problem exists from the phylogenetic point of view in establishing two different species, because both forms are monophyletic groups and some character discontinuities are observed, indicating no mixture between lineages (see De Queiroz and Donoghue 1990). 


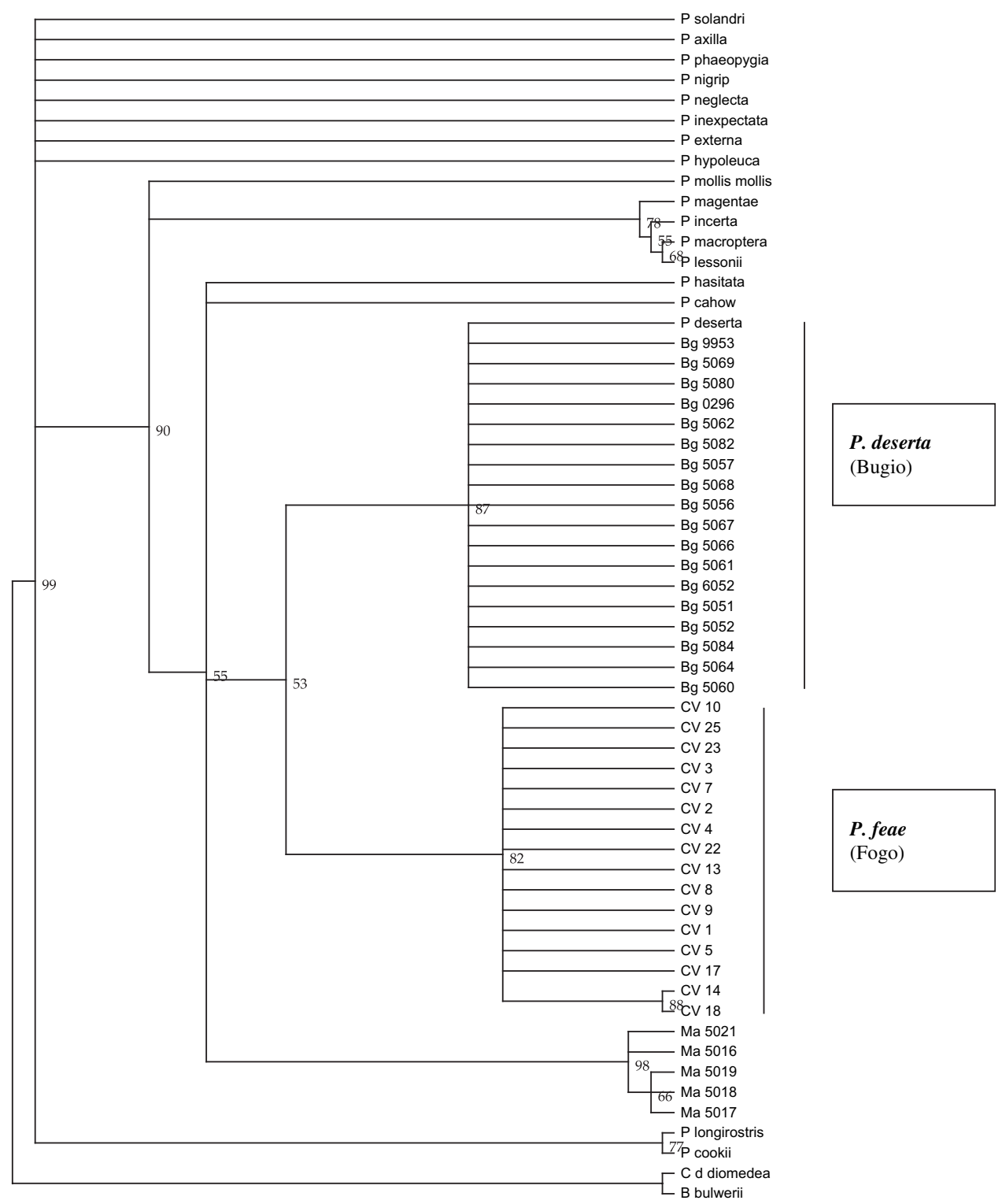

Figure 6. Bootstrap 50\% majority-rule consensus tree derived from a ML analysis. Nonparametric bootstrap support for nodes was estimated using the 'fast' option with 1oo heuristic bootstrap replicates implemented in PAUP* 4.obio. Polytomous nodes indicate that the resolutions of the nodes involved have bootstrap values less than 50 .

Despite significant differences in some morphometric characters, namely those related to bill size and tarsus length, (larger in Bugio), the overlap between intervals of variation is high, which hinders distinguishing individuals from the two species morphologically. We did not find conspicuous significant differences in colouration, although differences were noted by other authors (Bretagnolle 1995, Hazevoet 1995, Patteson and Brinkley 2004). Cape Verde petrels have darker upper tail coverts, moderate to heavy barring in the feathers of the sides near the base of 
the wings and heavily marked and mottled sides and flanks, which is rarely seen in the Bugio petrel. For these reasons, the two species should perhaps be considered cryptic as suggested by Ratcliffe et al. (2000).

\section{Conservation impact of these results}

According to Friesen et al. (2007a) the estimation or prediction of population differentiation of a species is an important issue for conservation. Molecular analysis of DNA sequences allows the identification of management units and evolutionary significant units that are fundamental in conservation. Modern conservation theory requires the definition of Evolutionary Significant Units (ESU) rather than inferences on fitness and diversity of populations and limits between species (Moritz 1994). Our data for Bugio and Fogo suggest the existence of two evolutionary significant units.

The major implication for conservation is that the world population of both species will now be reduced, and this may have implications for their regional (and perhaps global) threat status, perhaps leading to greater conservation efforts.

The combined taxon, Fea's Petrel P. feae, sensu lato, is currently listed by BirdLife International as 'Near Threatened' in the 2008 IUCN Red List, approaching the thresholds for 'Vulnerable' under criteria D1 and D2 (BirdLife International 2008, IUCN 2008). This is because although its total population size numbers just 3,000 individuals, current population trends are considered stable.

Following Cabral et al. (2005) and Birdlife International (2008) the conservation status of Bugio Petrel is 'Vulnerable' and 'Near Threatened', for Europe and the World respectively. Based on surveys in 2006-2007, 150-180 pairs breed on Bugio, where the population appears stable (D. Menezes and P. Oliveira in litt. 2007 to BirdLife International, 2008). If assessed for the global IUCN Red List, this taxon may qualify as 'Vulnerable' under criterion Di due to an extremely small breeding range $\left(<20 \mathrm{~km}^{2}\right)$ and the number of breeding pairs. The status of Cape Verde petrel is poorly known, therefore more studies are needed. The population has been estimated at 500-1,000 pairs, although this must be regarded as an absolute minimum as further colonies probably exist on Fogo and Santo Antão and individuals have also been observed breeding in the central mountain range of Santiago island (Ratcliffe et al. 200o, BirdLife International 2008). Without any evidence of declines, the taxon would qualify as 'Near Threatened' under criteria $\mathrm{D}_{1}$ and $\mathrm{D}_{2}$.

The efforts made to conserve these two species are very different. On Bugio the birds and their habitat are well protected and many projects are under way e.g. the Life project SOS Bugio Petrel (LIFEo6NAT/PT/ooo184). On the other hand, in Cape Verde, only a small part of the population benefits from a National Park established at Chão das Caldeiras on Fogo. Our findings underline the importance of promoting and implementing these and other conservation activities, with specific measures to locate the more important colonies, habitat preservation and protection of nesting sites.

\section{Acknowledgements}

This project was supported by the EC, through the Life project SOS Bugio Petrel (LIFEo6NAT/ PT/ooo184). We would like to thank the Cape Verde authorities for giving us permission to work in Chão das Caldeiras (Parque Natural do Fogo). We would like to thank Alexandre Nevsky and Berthold Seibert and their co-workers for all the help and general support, and Amilcar Vasconcelos, Pedro Gouveia, Isamberto Silva, João Gomes, Filipe Viveiros, João Paulo, Carlos Santos, Pedro Geraldes, Pedro Sepúlveda, Danilo Montraud and family, Félix M. Medina (Feluco) and Cátia Gouveia that shared many hours in the field, helping us with logistic support. We also thank Ana Teresa Fernández, and technicians from the Human Genetics Laboratory for Laboratory support. 


\section{References}

Báez, M. and Sánchez-Pinto, L. (1983) Islas de fuego y agua. Las Palmas de Gran Canaria: Ed. Edirca.

Bannerman, D. and Bannerman, W. M. (1965) Birds of the Atlantic islands. A history of the birds of Madeira, the Desertas, and the Porto Santo islands. Edinburgh: Oliver and Boyd.

Bannerman, D. and Bannerman, W. M. (1968) History of the birds of the Cape Verde islands. Birds of the Atlantic islands. Edinburgh: Oliver and Boyd.

BirdLife International (2008) Species factsheet: Pterodroma feae. Downloaded from www.birdlife.org on 13 October 2008.

Bourne, W. (1955) The birds of the Cape Verde Islands. Ibis 97: 508-556.

Bourne, W. (1957) Additional notes on the birds of the Cape Verde islands, with particular reference to Bulweria mollis and Fregata magnificens. Ibis 99:182-190.

Bourne, W. (1983) The Soft-plumaged petrel, the Gon-gon and the Freira, Pterodroma mollis, P. feae and P. madeira. Bull. Brit. Ornithol. Club 103: 52-58.

Bretagnolle, V. (1995) Systematics of the Soft-plumaged Petrel Pterodroma mollis (Procellariidae): new insight from the study of vocalizations. Ibis 137: 207-218.

Brooke, M. and Rowe, G. (1996) Behavioural and molecular evidence for specific status of light and dark morphs of the Herald Petrel Pterodroma heraldica. Ibis 138: 420432.

Cabral, J., Almeida, J., Almeida, P., Dellinger, T., Ferrand, A., Oliveira, M., Palmeirim, J., Queiroz, A., Rogado, L. and Santos-Reis, M. (eds.) (2005) Livro vermelho dos vertebrados de Portugal. Lisboa: Instituto da Conservação da Natureza.

Costa, F. (1998) Impactos geomorfológicos da erupção de Abril de 1995 na Ilha do Fogo (Cabo Verde). Garcia de Orta, Sér. Geogr. 16: $63-74$.

Cramp, S. and Simmons, K. E. (1977) The birds of the Western Palearctic. Vol. I. Oxford: Oxford University Press.

De Queiroz, K. and Donoghue, M. (1990) Phylogenetic systematics or Nelsońs version of cladistics? Cladistics 6: 61-75.
Farias, I., Ortí, G., Sampaio, I., Schneider, H. and Meyer, A. (2001) The cytochrome $b$ gene as a phylogenetic marker: the limits of resolution for analyzing relationships among Cichlid fishes. J. Mol. Evol. 53: 89-103.

Felsenstein, J. (1985) Confidence limits on phylogenies: an approach using the bootstrap. Evolution 39: 783-791.

Felsenstein, J. (1993) PHYLIP 3.5 (phylogeny inference package). Seattle: Department of Genetics, University of Washington.

Friesen, V., González, J. A. and Cruz-Delgado, F. (2006) Population genetic structure and conservation of the Galápagos petrel (Pterodroma phaeopygia). Conserv. Genet. 7: 105-115.

Friesen, V. L., Burg, T. M. and McCoy, K. D. (2007a) Mechanisms of population differentiation in seabirds. Mol. Ecol. 16: 17651785 .

Friesen, V. L., Smith, A. L., Gómez-Díaz, E., Bolton, M., Furness, R. W., González-Solís, J. and Monteiro, L. R. (2007b) Sympatric speciation by allochrony in a seabird. Proc. Natl. Acad. Sci. USA 104: 18589-18594.

Geldmacher, J., van der Bogaard, P., Hoernle, K. and Schmincke, H.-U. (2000) A-r age dating of the Madeira archipelago and hotspot track (eastern North Atlantic). Geochem. Geophys. Geosyst. I.

Gómez-Díaz, E., González-Solís, J., Peinado, M. A. and Page, R. D. M. (2006) Phylogeography of the Calonectris shearwaters using molecular and morphometric data. Mol. Phylogenet. Evol. 41: 322-332.

Hazevoet, C. (1995) The birds of the Cape Verde islands. Tring: British Ornithologists' Union.

Hernández-Fernández, M. and Vrba, E. S. (2006) Plio-Pleistocene climatic change in the Turkana Basin (East Africa): evidence from large mammal faunas. J. Hum. Evol. 50: 595-626.

Ho, S. Y. W., Phillips, M. J., Drummond, A. J. and Cooper, A. (2005) Accuracy of rate estimation using relaxed-clock models with a critical focus on the early metazoan radiation. Mol. Biol. Evol. 22: 1355-1363.

Huelsenbeck, J. P. and Crandall, K. A. (1997) Phylogeny estimation and hypothesis 
testing using maximum likelihood. Аnпи. Rev. Ecol. Syst. 28: 437-466.

Huelsenbeck, J. P. and Ronquist, F. (2001) MR-BAYES: Bayesian inference of phylogeny. Bioinformatics 17: 754-755.

Imber, M. J. (1985) Origins, phylogeny and taxonomy of the gradfly petrels Pterodroma spp. Ibis 127: 197-229.

Johnson, K. (2001) Taxon sampling and the phylogenetic position of Passeriformes: evidence from 916 avian cytochrome $b$ sequences. Syst. Biol. 50: 128-136.

Jouanin, C., Roux, F. and Zino, A. P. (1969) Visites aux lieux de nidification de Pterodroma mollis « deserta ». Oiseau 39: 161175.

Jouanin, C. and Mougin, J.-L. (1979) Order Procellariiformes. Pp. 48-121 in E. Mayr and G. W. Coterell, eds. Peters' check-list of birds of the world. Vol. 1. Second edition. Cambridge, MA: Harvard University Press.

Kimura, M. (1980) A simple model for estimating rates of base substitution through comparative studies of nucleotide sequences. J. Mol. Evol. 16: 111-120.

Kumar, S., Tamura, K. and Nei, M. (2004)

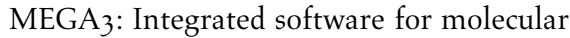
evolutionary genetics analysis and sequence alignment. Briefings in Bioinformatics 5: 150-163.

Mathews, G. M. (1934a) Remarks on the races of Pterodroma mollis. Bull. Brit. Ornithol. Club 54: 178-179.

Mathews, G. M. (1934b) A check-list of the order Procellariiformes. Novitates Zoologicae 39: 151-206.

Mayr, E. (1942) Systematics and the origin of species. New Work: Columbia University Press.

Mindell, D. P. and Honeycutt, R. L. (1990) Ribosomal RNA in vertebrates: Evolution and phylogenetic applications. Annu. Rev. Ecol. Syst. 21: 541-566.

Mitchell-Thomé, R. C. (1985) Radiometric studies in Macaronesia. Bol. Mus. Mun. Funchal 37: 52-85.

Monteiro, L. R. and Furness, R. W. (1995) Fea's Petrel Pterodroma feae in the Azores. Bull. Brit. Ornithol. Club 115: 9-14.

Monteiro, L. R. and Furness, R. W. (1998) Speciation through temporal segregation of Madeiran storm petrel (Oceanodroma cas- tro) populations in the Azores?. Phil. Trans. R. Soc. Lond. B. 353: 945-953.

Moritz, C. (1994) Applications of mitochondrial DNA analysis in conservation: a critical review. Mol. Ecol. 3: 401-411.

Nunn, G. B. and Stanley, S. E. (1998) Body size effects and rates of cytochrome $b$ evolution in tube-nosed seabirds. Mol. Biol. Evol. 15: 1360-1371.

Patteson, J. B. and Brinkley, E. S. (2004) The gadflies of North Carolina. Birding (Dec 2004): 586-596.

Posada, D. and Buckley, T. R., (2004) Model selection and model averaging in phylogenetics: advantages of the AIC and Bayesian approaches over likelihood ratio tests. Syst. Biol. 53: 793-808.

Posada, D. and Crandall, K. A. (1998) Modeltest: testing the model of DNA substitution. Bioinformatics 14: 817-818.

Proudlove, G. and Wood, P. J. (2003) The blind leading the blind: cryptic subterranean species and DNA taxonomy. Trends Ecol. Evol. 18: 272-273.

Rambaut, A., and Drummond, A. (2005) Tracer. A program for analysing results from Bayesian MCMC programs such as BEAST and MrBayes. Version 1.3. Available in http://evolve.zoo.ox.ac.uk/software.html? id $=$ tracer

Ratcliffe, N., Zino, F. J., Oliveira, P., Vasconcelos, A., Hazevoet, C. J., Costa Neves, H., Monteiro, L. R. and Zino, F. (2000) The status and distribution of Fea's Petrel Pterodroma feae in the Cape Verde Islands. Atlantic Seabirds 2: 73-86.

Rodríguez, F., Oliver, J., Marin, A. and Medina, J. (1990) The general stochastic model of nucleotide substitutions. J. Theor. Biol. 142: 485-501.

Sangster, G., Knox, A., Helbig, A. J. and Parkin, D. T. (2002) Taxonomic recommendations for European birds. Ibis 144: 153159.

Smith, A. L. and Friesen, V. L. (2007) Differentiation of sympatric populations of the band-rumped storm-petrel in the Galapagos islands: an examination of genetics, morphology, and vocalizations. Mol. Ecol. 16: 1593-1603.

Stanley, S. and Harrison, R. G. (1999) Cytochrome $b$ evolution in birds and mammals: 
an evaluation of the avian constraint hypothesis. Mol. Biol. Evol. 16: 1575-1585.

Swofford, D. L. (2002) PAUP*: Phylogenetic analysis using parsimony (and other methods) 4.o.b1o. Sunderland, MA: Sinauer Associates.

Swofford, D. L., Olsen, G. J., Waddell, P. J. and Hillis, D. M. (1996) Phylogenetic inference. Pp. 407-515 in D. M. Hillis, C. Moritz and B. K. Mable. Molecular systematics. 2nd ed. Sunderland, MA: Sinauer Associates.

Tamura, K., Dudley, J., Nei, M. and Kumar, S. (2007) MEGA4: Molecular Evolutionary Genetics Analysis (MEGA) software version 4.0. Mol. Biol. Evol. 24: 1596-1599.

Teixeira, C., Pais, J. and Rocha, R. (1979) Quadros de unidades estratigráficas e da estratigrafia portuguesa. Lisboa: Instituto Nacional de Investigação Científica.

Thompson, J. D., Higgins, D. G. and Gibson, T. J. (1994) Clustal W: improving the sensitivity of progressive multiple se- quence alignment through sequence weighting, position specific gap penalties and weight matrix choice. Nucleic Acids Res. 22: 4673-468o.

Xia, X. and Xie, Z. (2001) DAMBE: Data analysis in molecular biology and evolution. J. Hered. 92: 371-373.

Warham, J. (1990) The petrels: their ecology and breeding systems. New York: Academic Press.

Zhang, D. X. and Hewitt, G. M. (1996) Nuclear integrations: challenges for mitochondrial DNA markers. Trends Ecol. Evol. 11: 247-251.

Zino, A. and Zino, F. (1986) Contribution to the study of the petrels of genus Pterodroma in the Archipelago of Madeira. Bol. Mus. Mun. Funchal 38: 141-165.

Zino, F., Brown, R. and Biscoito, M. (2008). The separation of Pterodroma madeira (Zino's Petrel) from Pterodroma feae (Fea's Petrel) (Aves: Procellariidae). Ibis 150: $326-$ 334 .

\section{JOSÉ JESUS*}

Human Genetics Laboratory, University of Madeira, Campus da Penteada, 900o-39o Funchal, Madeira, Portugal and Centre for Environmental Biology, Faculty of Science of Universidade de Lisboa, Campo Grande, 1749-o16 Lisboa, Portugal.

\section{DÍLIA MENEZES, PAULO OLIVEIRA}

Parque Natural da Madeira, Quinta do Bom Sucesso, Caminho do Meio, 9050-251 Funchal, Madeira, Portugal.

\section{MANUEL NOGALES}

Island Ecology and Evolution Research Group (IPNA-CSIC), Astrofísico Francisco Sánchez no. 3, 38206 La Laguna, Tenerife, Canary Islands, Spain.

\section{SARA GOMES, ANTÓNIO BREHM}

Human Genetics Laboratory, University of Madeira, Campus da Penteada, 90oo-39o Funchal, Madeira, Portugal.

*Author for correspondence; email: Jesus@uma.pt

Received 7 May 2008; revision accepted 17 October 2008 